\title{
EDITORIAL
}

\section{Una perspectiva estratégica para el desarrollo de la agricultura en la Región de Arica y Parinacota}

\author{
A strategic perspective for the development of agriculture \\ in the Región de Arica y Parinacota
}

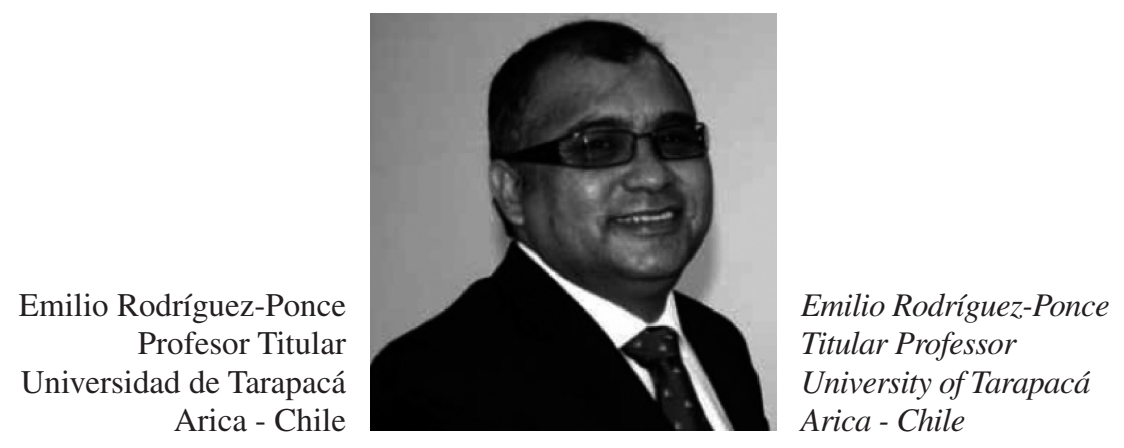

Pensar estratégicamente implica realizar una proyección de un futuro deseable, buscando un posicionamiento de largo alcance, en un escenario en el cual se logre alcanzar una ventaja competitiva sustentable. En efecto, la perspectiva estratégica es natural e inherente al campo de las organizaciones, pero también es susceptible de aplicarse al ámbito del desarrollo territorial.

Precisamente, el alineamiento de los recursos y las capacidades institucionales con los requerimientos del entorno se constituyen en una condición esencial -aunque no suficiente- para lograr un posicionamiento estratégico exitoso. Esta no es una tarea fácil, ya que se requiere la definición de objetivos claros y sencillos, junto con un análisis profundo del entorno, una valoración objetiva de los recursos y las capacidades, pero a todo lo anterior se debe agregar la necesidad de una implementación eficaz.

Así, emerge la interrogante respecto a: ¿Cómo desarrollar la agricultura en la Región de Arica y Parinacota en un contexto de: escasez hídrica, altos niveles de contaminación de las aguas, cambio climático, elevadas condiciones de salinidad, deficiente calidad de los suelos y escasas hectáreas cultivables (menos del 10\% de las hectáreas existentes en la Región de Tacna)? La segunda pregunta es: ¿Si lo anterior fuera posible, adicionalmente, podría la agricultura transformarse en un eje estratégico y prioritario de desarrollo para la Región?
Thinking strategically implies making a projection of a desirable future, looking for long-term positioning in a scenario that will allow a sustainable competitive advantage to be achieved. The strategic perspective is natural and inherent in the organization field, but may also be applied in the area of territorial development.

The alignment of resources and institutional capacities with the requirements of the environment constitutes a necessary -although not sufficient-condition to reach a successful strategic positioning. This is not an easy task, since it requires defining clear and simple objectives, together with a profound analysis of the environment, an objective valuing of the resources and capacities, along with the requirement of efficient implementation.

Thus questions arise with respect to how to develop agriculture in the Region de Arica y Parinacota in view of the scarcity of water, climate change, high levels of salinity, the deficient soils and the few cultivatable hectares (less than 10\% of the land area of the neighboring Región de Tacna in Peru). Secondly, if this is possible, could agriculture be transformed into a strategic axis and development priority for the region? 
El Plan de Desarrollo de Zonas Extremas diseñado en el año 2014 realiza una apuesta inédita en la historia de la agricultura del extremo norte de Chile. En su diseño conceptual subyacen una serie de elementos estratégicos que bien vale la pena hacer explícitos. Se trata de un programa de Gobierno que apuesta a la Agricultura como uno de los motores fundamentales del desarrollo sustentable de la Región.

¿Cómo puede adoptarse una decisión de tal naturaleza con la presencia de tantos elementos en contrario? Primero se debe reconocer que la agricultura regional se sustenta en los Valles de Azapa, Lluta y Camarones, a los que se suman Codpa, Acha y Vitor, aunque estos últimos mantienen una agricultura de subsistencia. Las limitaciones de recursos hídricos y condiciones del agua, la adversas características de los terrenos y escasez de hectáreas cultivables son ciertas, pero lo valles de la Región tienen como elemento diferenciador, la realización de cultivos contra estación generando - de este modo- primores en épocas del año en que los restantes valles de Chile no tienen cultivos equivalentes.

Segundo, los genes de los productos regionales son de tal calidad que tienen resistencia a la salinidad, al boro, y a condiciones de suelo adversas, permitiendo cultivos en una zona árida, naturalmente con escasez hídrica, y logrando por lo demás propiedades organolépticas excepcionales $-\mathrm{O}$ al menos altamente deseables-en la mayoría de los casos.

Por consiguiente, el clima y la calidad genética de los cultivos permiten una posición competitiva de liderazgo o incluso de cuasi monopolio en determinadas épocas del año. Esta es -sin duda- una fuente de ventaja competitiva innegable que ha permitido sustentar por décadas la actividad agrícola de la Región, pero que debidamente potenciada como una capacidad estratégica esencial puede -adicionalmentepermitir elevados niveles de desarrollo para la agricultura y para economía Regional.

Dicho de modo claro, la posibilidad real de lograr primores, es decir, cultivos en tiempos en que no existe una competencia relevante es una condición ejemplar de ventaja competitiva. Más aún, si se considera que tales cultivos tienen características organolépticas deseables y pueden lograr una identidad propia mediante la denominación de origen. En definitiva, la presencia como primor,
The Development Plan for Extreme Zones designed in 2014 makes a bet unprecedented in the history of agriculture of extreme northern Chile. Its conceptual design includes a series of underlying strategic elements that are worth making explicit. This is a government program that bets on agriculture as one of the fundamental motors of sustainable development of the region.

How can a decision of this nature be taken in the presence of so many contrary elements? It must first be recognized that regional agriculture is sustained in the Azapa, Lluta and Camarones valleys; the Codpa, Acha and Vitor valleys have only subsistence agriculture. In spite of the limitations and conditions of the water, the adverse characteristics of the soils and the scarcity of cultivatable hectares, the possibility of off-season crops generates an opportunity to produce in seasons when valleys in the rest of Chile cannot do so.

Second, the species varieties of the regional products are resistant to salinity, boron and the adverse soil conditions, allowing crops in an arid zone where water is necessarily scarce, and also producing crops with exceptional (or at least highly desirable) organoleptic properties in most cases.

Thus the climate and the genetic quality of the crops allow a competitive position of leadership, and almost a monopoly in some seasons of the year. This is an undeniable competitive advantage that for decades has sustained the agricultural activity of the region. Correctly empowered as an essential strategic capacity it may also allow high levels of development for the regional agriculture and economy.

Clearly stated, the real possibility of producing crops at times where there is no relevant completion is a prime condition for competitive advantage. Even more, considering that these crops have desirable organoleptic properties and may achieve their own identity with the designation of origin. The existence of high-quality, off-season products with designation of origin provides great strategic value and a competitive advantage of maximum relevance.

Under these premises, a perspective strategy produces a set of vital projects for long-term 
de alta calidad, y con denominación de origen constituye un valor estratégico de marca mayor y una ventaja competitiva de la máxima relevancia.

Bajo estas premisas -con perspectiva estratégica- emergen un conjunto de proyectos vitales para un desarrollo de largo alcance de la agricultura en Arica y Parinacota. Entre estos proyectos estratégicos -debidamente considerados en el Plan de Zonas Extremas- se pueden destacar:

- Proyectos de inversión pública que incrementan el agua de riego, tales como el entubamiento del canal Azapa, el embalse Chironta, el embalse Umirpa, y el embalse Livílcar. A lo que se sumaría la planta desaladora reduciendo la extracción de agua del acuífero de Azapa y un conjunto de programas que permitan la recuperación permanente de canales y la construcción de acumuladores de agua.

- Proyectos de inversión pública mitigadores de contaminación, necesarios para enfrentar uno de las problemáticas más agudas principalmente para el valle de Lluta derivadas de las aguas del Río Azufre y otros caudales afectados por explotaciones mineras que requieren estudios e inversiones concretas para aminorar a niveles adecuados la contaminación.

- Proyectos de inversión pública y privada alta tecnología y sustentabilidad, que estimulen la instalación en los valle de sistemas de riego tecnificados y gestionados por medios informáticos de alta precisión, incorporando las ventajas que implica el cultivo sin suelo para incrementar significativamente la productividad de los valles, en un marco del cumplimiento de estándares de sustentabilidad y preservación del medio ambiente.

A lo anterior debe sumarse una política que permita solo el ingreso de productos agrícolas foráneos que cumplan con los más altos estándares de exigencia y calidad, garantizando un control riguroso y exhaustivo de los mismos.

Por lo tanto, con una mirada estratégica, sí resulta posible que la agricultura de la Región de Arica y Parinacota progrese y se desarrolle de modo sustentable, con un posicionamiento de privilegio y con ventaja competitiva, siendo un área que -adicionalmente- aporte significativamente al desarrollo territorial. development of agriculture in Arica y Parinacota. Among these strategic projects -appropriately considered in the Plan for Extreme Zones- may be highlighted:

- Projects of public investment that increase irrigation water, such as the intubation of the Azapa Canal, the Chironta, Umirpa and Livilcar dams, a desalinization plant (reducing the extraction of water from the Azapa aquifer) and a set of programs that would allow the permanent recovery of canals and the construction of water accumulators.

- Projects of public investment to mitigate contamination, which are necessary to solve one of the thorniest problems of the water, mainly in the Lluta Valley derived from the water of the Rio Azufre and others affected by mine exploitation. These require studies and specific investments to reduce the contamination to acceptable levels.

- Public and private investment products of high technology and sustainability that will stimulate the installation in the valleys of technical irrigation systems controlled by high-precision computer media, incorporating the advantages inherent in soilless cultivation to increase significantly the productivity of the values in the framework of complying with sustainable standards and environmental conservation.

There should also be a policy that only allows foreign agricultural products to be admitted if they fulfil the highest standards of exigency and quality, guaranteeing their rigorous and exhaustive control.

Thus from a strategic viewpoint, it is possible for the agriculture of the Región de Arica $y$ Parinacota to progress and develop sustainably, with a privileged position and a competitive advantage; this is an area which additionally provides significant input to territorial development. 